Ayurlog: National Journal of Research in Ayurved Science

\title{
An Ayurvedic approach of constipation
}

\section{Shweta D. Parwe ${ }^{* 1}$, Nisargandha M. A. ${ }^{2}$}

1. Department of Panchakarma, MGACH \& RC, Salod (H) WARDHA, Maharashtra.

2. Department of Physiology, SMBT Institute of Medical Sciences \& Research Centre, Dhamangaon, Nasik., Maharashtra

*Corresponding Author- drshwetaparve@gmail.com

\section{Abstract-}

Ayurveda believes in the doshik theory of disease. The balanced state of these doshas is health and imbalanced state of the doshas is called disease. The equilibrium of these three basic substances is responsible for maintaining good health. Similarly disequilibrium of these ma cause disintegration of the body or may lead to death.

Constipation may be associated with an organic local lesion or generalized systemic disease. In the majority of cases constipation is a functional disorder caused due to delay in the passage of fecal matter or due to an insufficient bulk of the feces.

Keywords - Ayurveda, Constipation, Health, Disorder.

\section{Introduction-}

Ayurveda believes in the doshik theory of disease. The balanced state of these doshas is health and imbalanced state of the doshas is called disease (1). This imbalance is usually because of the vitiation of a particular dosha single or in combination of others. The causes of the imbalance of dosha have been described under 'Nidan' or 'Hetu' (2). When causative factors operate on the body, the doshas are excited and spread all over body through certain channels called as 'Strotas' (3). Ultimately they involve certain tissue structures of a particular organ or system and produce, signs and symptoms of a particular disease which are mentioned under 'Purvarupa and Rupa'(4) (5).

This entire phenomenon right from the vitiation of dosha to the production of disease is known as ' Samprapti '(6). As defined by Vagbhata, samprapti is the science of disease which deals with the process of vitiation of dosha; they are spread all over the body with the manifestation of signs and symptoms of the disease. Thus the study of entire changes taking place in the body under the influence of etiological factors leading to the production of the disease is known as 'Nidan panchaka (7). It deals with the body changes both at the clinical as well as subclinical stages of the diseases.

In this connection, Vagbhata, pertinently states that

The physician should first seek the nature of the disease, the derangement caused by the Dosha and Dhatu, the organ where the derangement is manifested and 
the causes which are responsible for this derangement, begin to start the disease. The physician examining the patient must consider, the condition of the dhatu and the malas, the place of his residence, his strength and the power of digestion, body constitute and diathesis, the age, the mental state, the habit and idiosyncrasies, the food usually taken and other minute items related to the patient and then arrive at a diagnosis and commence the treatment. One who will follow their method will never commit any mistake (8).

\section{1) AYURVEDIC CONCEPT}

\section{MALAVSHTAMBHA}

Ayurveda respects the theories of creation of the Universe. Life begins when soul enters the fertilized ovum and it relies on the dominance of mahabhuta. So all living beings are created by combination of five basic elements and the Soul, Akash, Vayu, Tej, Aapa \& Prithvi are the fiv basic eternal substances, designed Panchamahabuta (9). The glory of Ayurveda lies in its evaluation of a theory of the maintenance of health and genesis of disease. The Ayurvedic theory of tridosha stands for all times and circumstances and justifies the ancient needs and caring for the future. These three doshas maintain the integrity of the human body. The equilibrium of these three basic substances is responsible for maintaining good health. Similarly disequilibrium of these may cause disintegration of the body or may lead to death (10) (11). There are three main malas Shakrut, Sweda and Mutra. Kitta is produced after the digestion of food material in the large intestine. The undigested food residue which is expelled out of pakvashaya with the help of apan vayu is called purisha to which this topic is related i.e. purishavastambha means malavstambha.

\section{About Mala \\ Vyakhya:}

After digestion, food is divided in two parts, sara and kitta. Sara bhag is known as Aahar rasa, while kitta bhag is known as mala, sweda, mutra, purisha etc. are nourished by this second part of digestion i.e. kitta bhag (12).

Charka in Sharirasthana has given clarification of mala i.e.

Body constituents (dhatu) are of two types, mala and Prasad, Mala part is that which is harmful to the body and it is produced in hollow space in the body and is evacuated through the external opening i.e. 'khamala' (wax formation in ear, slimy sticky discharge from eyes, discharge from nose etc.) vitiated dosha and anything which are harmful to the body are called as mala (13).

\section{amyak Malapravrutti:}

Though having mutrapravrutti without malapravrutti gas excreted, Agni becomes Pradipta, kostha become light (14).

Malavstambha is related with purishmala.

\section{About Purishmala}

The term mala has been defined as "mrijyate shodhyate" meaning to clear out or to purify.(c.r.das physiology in Ayu, chaukhamba Sanskrit sansthan)

\section{Vyakhya:}

After division of Sara and kitta, again kitta is divided into two parts, the liquid part is known as Muttra, while the solid part is known as Shakrut or Purisha (15).

\section{Praman:}

The quantity of purisha is said to have owned seven Anjaali (16).

\section{Swarupa:}


Even though purish is panchabhautic in nature, vayu and Agni are more dominant (17).

\section{Rasa:}

The rasa of purisha is katu (18).

\section{Varna and Gandha:}

The normal color of purisha is yellow and having a typical smell i.e. purisha gandha (19).

\section{Purish aunsha:}

It contains three main parts.

1. Annasya anusha: After digestion some part of food which is digested or not digested is present in stool.

2. Dhatuna anusha: The process of digestion is continuously going on in the body, from which formation of dhatus takes place. During this process waste products are formed which come into intestine and mix with purisha.

3. Malinvata aunsha: during digestion gases are formed and these gases come ou with purisha.

\section{Koshtha:}

Digestion is important in the formation of mala. The process of digestion takes place in the koshtha. Three types of koshtha are mentioned i.e. krura koshtha having dominance of vatakapha, in which the virechan should be given with tikshna dravyas in large quantity.

Mrudu koshtha is dominance of pitta; in which virechan should be given with mrudu dravyas in less quantity. Madyam koshtha is of samadoshaja, in which virechan should be given in madhyam matra. In mrudu koshtha the symptoms of samyak sneha are seen within 3 days, in sadharan koshtha after 5 days and in krura koshtha after 7 days.

\section{Purishvaha Strotas:}

Roots of the purishvaha strotas are pakvashaya and, sthulaguda (20).
Suppression of the urge of defecation, consumption of excessive food, indigestion of good, eating in quick succession, hampered digestive power and starvation are the etiological factors to vitiate the purishvaha strotas (21).

\section{Dushti Lakshane:}

When purishavaha strotas is vitiated the purisha is evacuated with difficulty or with efforts. In that case the quantity is less and its movement is painful and with particular sound.

The stool defecated liquid or loose, hard, granular and in excessive quantity (22).

\section{Purishdhara kala:}

This purishadhara kala is of fifthThis is in the anthakoshtha, between, last parts of laghwantra and starting part of bruhadantra known as unduka. Here the separation of rasa, mutra and purisha takes lace. This fiction of separation is due to ata and Agni (23).

Separation of mala is more in pakvashaya. Here liquid waste material is separated and it sends towards basti and solid part of the waste remains there (24).

This Guda (anus) is divided into two parts - uttarguda and adharguda. In uttarguda purisha mala is stored while by adharguda this stored purishmala is evacuated (25).

The guda is in apan region. While in uttarguda, purishmala is stored at the same time adharguda remains empty. When food comes from digestion, the process starts under the control of pranvayu. Pran helps saman and apan vayu for forward movements of intestine.

Because of this movement, mala comes into unduka and then it enters into the uttarguda, which gets enlarged and produce an urge for evacuation of purishamala. This urge helps to increase 
the function of apana and movements of guda. The contraction of abdominal muscles and vitapa muscles helps to increases the pressure on the guda, due to which the adharguda opens through which the purish mala is evacuated. Stopping a breath for some period by udana, helps to put more pressure on guda. All these interconnected functions help to normal evacuation of purishamala.

The guda is made up of three folds i.e. Pravahini, Visarjani and Sanvarni. The last Part, sanvarni is under control of prana. So it is possible to control the urge for some time. If this happens recurreritly its affects the sensations of urge leading to malavstambha. This clearly indicates that, three is relation between body and mind.

\section{Purisha Karma:}

Purishamala should remain in pakvashaya or purishdharakala for some time to maintain proper functions dhatus. If this purishamala is evacuated large quantity,

Recurrently, it affects all dhatus.

The function of purishamala is to support or to stabilize the body (26) (27).

Purisha formation takes place in pakvashaya. In third stage of digestion katu rasa is formed, which helps to support vata. This vata controls the movements of intestine. The movement of large intestine is comparatively less than that of duodenum and small intestines. If the movements of intestines get disturbed, it affects digestion process, due to which, undigested food materials evacuated through guda. To stop this process of indigestion, movements should be balanced by purisha with the help of vata and Agni.

If purishmala is evacuated in less quantity then it causes accumulation of Purishamala and if it is evacuated in large quantity then it causes decrease in Purishmala. The decrease of purishamala is harm full to body vis-a-vis the increase of Purishmala, so purishakshaya should be controlled (28).

\section{Purisha Vrudhikar Lakshane:}

If purisha increases, it causes flatulence, heaviness and pain in abdomen (29).

\section{Purisha Kshaya Lakshane:}

If purisha is decreased it causes, flatulence, twisting like pain in abdomen. Gases distention causes pain in chest, sternum and heart (30).

\section{ABOUT AVASTAMBHA}

Nirukti:

$$
\text { अव् +स्तम्भ् +धज् }
$$

\section{Paryayi Name:}

Adhar, Roka, Ashraya, Sahasa, Ahankar, Drudhanicchaya, stambha, Pakshaghata, Sona, Stabdhata, Upakram, ramba, Thehrana.

\section{yakhya:}

The meaning rokana, thehrana, stambha and stabdhata are related with malavstambha. In Ayurvedic literature Avastambha means Dharan. This avastambha is Marathi version meaning avarodha. Malavstambha means there is change in natural evacuation of stool i.e. irregular evacuation of hard stool.

\section{ABOUT MALAVSTAMBHA}

\section{Synonyms of Malavshtambha}

Vibhandha, malavrodha, Vitgraha, Kabja, Anaha, Koshtabadhata.

\section{Hetu:}

Vishamashan, adhyashan, langhan, guru, ruksha, vistambhi, picchil, fermented food, Night works, sleeping in day time, ati-vyayam, ati-maithuan, vega-vidharan mansik chinta vyagrata, agnimandya, atisheet padartha sevan etc.

Purva - Rupa: 
Heaviness in lower abdomen, irregular bowel habits, loss of appetite, bad smell or Gases etc.

\section{Rupa:}

Pravahan, Shushka and grathil mala, adhaman, atup, udar-shool, shirshool and

Unustahi, aniyamita and sakashtha malapravruti, ajirna, hrullasa, udar-daha, amlodgar, urodaha, anidra, swapandhikya, alasya, mana-aswasthya.

\section{Prakar:}

1. Vata pradhan malavstambha: Stool is shushkha, grathil, shul, flatulence and Pravahan.

2. Vatakapha pradhan malavstambha: Stool is picchil, sheethil, Pravahan, and adhodar-guruta. Mukha-dourgandha, mukha-prasek and kshudha - alpata.

\section{Samprapti:}

When the stools become hardened, dense, knotted, dry and waffed on by Vata the Channel become closed up causing rectal edema aggravated by this reason only; Vayu moves upwards and stay blocked in the pelvic region, back and cardiac or chest region. It also gathers up at the head and causes many types of distortions - deafness, darkness, catanah and so on. In addition, this vata also disturbs pitta and kapha from their own natural sites and as it is running out (hither and thither), the seven dhatus like ras and others become vitiated (31) (Bhel San SU23/1-4).

\section{Chikista:}

Therefore when a person develops tenable malavstmbha, he should give up eating Dry fruits and he should never be purgated. Unctuous and charming foods are varied types of meats accompanied with Kulattha rasa should be given enema with decoctions as well as medicated oils. For a person who counteracts, no distortions (due to hardened stools) will arise. Do not give hard purgatives just treat this patient with anuloman? (32) (Bhel Sam SU23/6-8)

\section{Upadrava:}

A powerful fever, pallor may also arise and the sneezing occurs and the grahani get vitiated. Nidranash, shirshul, udarshul, udavarta, arsh, parikartika, gudabhransha.

\section{Sadhya Sadhyatwa -}

New malavstarnbha is sukh-sadhya while chronic malavstambha is kasthasadhya. In old age it is yapya or asadhya(33). ( Bhel Sam SU23/5 P.G.102)

\section{Pathya - Apathya}

Diet - Milk, raw food green vegetables, mainly vegetable food which is easy to digest. Exercise, walking, Yogasana(34). ( Bhel Sam SU.23/6 P.G.102)

\section{MODERN CONCEPT about the} Malavstambha CONSTIPATION

Definition: Constipation implies irregular and incomplete evacuation of hard, dried feces.

Etiology: Constipation may be associated with an organic local lesion or generalized systemic disease. In the majority of cases constipation is a functional disorder caused due to delay in the passage of fecal matter or due to an insufficient bulk of the feces. The important cause is the bad habits of neglecting the urge or nature's call for defection. Because of this the reflex is lost. Due to intake of low residue diet or starvation there may not be enough fecal matter to produce bowel evacuation. In some persons an autonomic imbalance of the nervous system produces spasticity of the colon which results in the constipation. In some disease like vomiting, pyloric 
obstruction, carcinoma, diverticulitis, painful defecation due to fissures, Thrombosed piles, abscess in the anal region etc tends to produce a fear of defecation which leads to constipation. Many drugs are commonly cause constipation. The persistent use of purgatives and enemas are the commonest and routine causes, which convert an occasional iron-evacuation of the bowel in chronic constipation. Rare cause of constipation is diabetes; mesoderm etc. The main important cause is posture of defecation.

Along with these etiological factors responsible for constipation are lacks of exercise, inadequate allotment of time for full defecation and prolonged travel. When the patient also ha s symptoms such as fatigue, malaise, headache or anorexia, the possibility should be considered whether such symptoms reflect an underlyin depression of which constipation is on component. Decreased colonic motility is responsible for the constipation insufficient water intake is one of the major causes for constipation in India. Sometimes acute constipation may be seen in acute intestinal obstruction, acute appendicitis, haematemesis etc.

\section{Causes of Constipation}

Physically, there are three main causes for the diagnosis of constipation.

\section{Obstruction in colon}

For the peristaltic movements of the intestine, enough quantity of liquid (H20) \& Fibrous diet is necessary. The intestine get exhausted because of the less quantity of these two substances for expulsion of substances with less quantity of fibrous \& $\mathrm{H} 20$ from intestine, the mucosal muscles of intestine has to produce more spasmodic peristaltic movement \& patient feels severe pain in abdomen. So excreted product did not expelled quickly. The stored mala become dried. This stage is called as 'colonic stasis'.

\section{Obstruction of Rectum}

Normally, patient has naturally peristaltic movement. But irregular \& modem life Style causes hesitation of malaveg pravrutti \& due to irregular habit of malaveg pravrutti muscles become weak \& do not expel the mala. Then the sensation of malaniskriman decreases slowly \& so this produce malavrodha. This stage is called as 'Rectal Stasis.'

\section{Intestinal Obstruction}

As irregular habits of eating \& excreting are becoming common in today's life style, abnormal dilatation \& narration of colon get produced which in turn causes obstruction of intestine. This obstruction decreases forward expulsion of mala \& mala retention gets produced. This tage is called as ' Intestinal Obstruction '.

\section{Simple Constipation}

a) Dietary Factors - fiber deficiency

b) Abuse of laxatives

c) Diminished expulsive power due to weakness of abdominal muscle or of pelvic floor.

d) Antony or delay in the return due to suppressed call to stool improper lavatory facilities.

5. Associated with disordered motility

Idiopathic slow transit constipation idiopathic mega colon \& mega rectum, irritable bowel syndrome.

6. Abnormal neurological control

Psychological factors can produce constipation through an inhibitory effect on the extrinsic autonomic innervations in the large bowel.

b) Spinal or Pelvic nerve injury - 
c) Hirschsprunrg's, disease in which there is an absence of nerves in wall of the bowel \& defective peristalsis. Chronic laxative abuse (possibly permanent damage to nerve plexuses)

7. Obstruction - : Tumors, Inflammation, Ischemia, Diverticular disease.

8. Drugs -: Narcotic analgesics (codeine \& Morphine) drugs with anti cholinergic side effects (tricyclic antidepressants, phenothiazines \& drugs used to treat urinary incontinence) \& Aluminum salts.

9. Other causes - : Parkinson's disease, Hypothyroidism,

Hypocalcaemia,

Depression.

10. Morning rush syndrome: - Where there is an urgent desire to deface ate several times on rising $\&$ after breakfast is common in irritable bowel syndrome patient may use the word constipation to express the sensation of incomplete defecation.

Clinical Features: In severe condition mechanical distention of rectum and colon by feces and colonic neurosis are seen.

Pathology: Hard stools are usually due to increased absorption of fluid as a result of prolonged contact of the luminal content with the colonic mucosa constituent to delayed transit.

In many instances emotional state and psychological stress is the altered bowel habits.

Types: Usually it is seen in chronic conditions but in some diseases it is seen in acute phase. Davidson and Macleod (1973) mentioned that chronic constipation is generally

Considered to be of two main types,

1. Colonic constipation.

2. Dyschezia constipation.

Physical Examination: -The finding of rectum distended with feces coupled with an absence of any desire to defecate is path gnomonic of dyschezia. Feces may be palpated in the sigmoid colon.

Investigations: $\quad$ - $\quad$ Radiological examination may be necessary, proctosigmidoscopy and a barium enema are necessary to exclude associated conditions such as piles, fissure etc.

Treatment: - Simple constipation:

A. Bowel habit - regular period of evacuation every morning.

B. Diet - high residue diet, plenty of brown bread, butter, fresh fruit, salads, vegetables, at least four pints of fluids daily.

C. Treatment of cause - omission of causative drug.

D. Hydrogogue preparations - to increase the bulk stimulation such as Isogel of Isobgol.

E. Laxatives - Busacody 5-20 mg/day, enna $7.5-3 \mathrm{mg} /$ day or Danthron 75$50 \mathrm{mg} /$ day.

F. Prolonged intake of these drugs may cause constipation by damaging the mesenteric Plexus.

G. Stool softener - Dioctyl sodium or calcium sulphosuccinate.

Enema or suppository.

H. Surgery - for treatment of rectocele etc.

I. Psychotherapy and biofeedback training to induce normal relaxation of pelvic floor During defection may help in same with idio pathic constipation.

Complication: The important complication of constipation is fecal impaction.

\section{References}

1. Sushrut Samhita (Hindi) (Varanasi Chaukhamba Orientalia reprint $4^{\text {th }}$ edition 1980, (Su.su.15/48). 
2. Madhav Nidan Of Shri Madhavkara With The Madhukosh Sanskrit Commentory Part I By Yadunandan Upadhyaya, Chaukhamba Prakashan Reprint Vi.Sa. 2065 (1/4).

3. Shastri, Charak Samhita vol. I (Hindi) (Varanasi Chukhamba Bharati Academy $20^{\text {th }}$ edition 1994, (Cha.Su.30/12).

4. Madhav Nidan,Of Shri Madhavkara With The Madhukosh Sanskrit Commentory Part I By Yadunandan Upadhyaya, Chaukhamba Prakashan Reprint ,Vi.Sa.2065 ( 1/5-6).

5. Garde G.K., Sartha Vagabhat (Marathi), Mumbai Gajanan Book Depot, $7^{\text {th }}$ edition 1983, (VA.NI. 1).

6. ashtang hridayam of vagbhata edited by with the vidyotini hind commentory by kaviraj atridev gupta published by Chaukhamba Sanskrit Sansthan, Varanasi, Reprint Vi.Sa. 2062, (A.H.NI.1/8).

7. Ashtang Hridayam Of Vagbhata Edited By With The Vidyotini Hindi Commentory By Kaviraj Atrideva Gupta Published By Chaukhamba Sanskrit Sansthan, Varanasi, Reprint Vi.Sa. 2062. (A.H.NI.1/2).

8. Garde G.K., Sartha Vagabhat (Marathi), Mumbai Gajanan Book Depot, $\quad 7^{\text {th }} \quad$ edition 1983 , (VA.SU.13/66-68).

9. Sushrut Samhita (Hindi) (Varanasi Chaukhamba Orientalia reprint $4^{\text {th }}$ edition 1980, (Su.Sha.1/14).

10. Sushrut Samhita (Hindi) (Varanasi Chaukhamba Orientalia reprint $4^{\text {th }}$ edition 1980, (Su.Su.21/3).
11. Ashtang Hridayam Of Vagbhata Edited By With The Vidyotini Hindi Commentory By Kaviraj Atrideva Gupta Published By Chaukhamba Sanskrit Sansthan, Varanasi, Reprint Vi.Sa. 2062, (A.H.Su.1).

12. Shastri, Charak Samhita vol. I (Hindi) (Varanasi Chukhamba Bharati Academy 20 ${ }^{\text {th }}$ edition 1994, (Cha. Su. 28/4).

13. Brahmananda Tripathi, Charak Samhita vol. I (Hindi) (Varanasi Chaukhamba Surbharati Prakashan, reprint edition 2001, (Cha. Sha. 6/17).

14. Garde G.K., Sartha Vagabhat (Marathi), Mumbai Gajanan Book Depot, $7^{\text {th }}$ edition 1983, (Va. Chi. 10/23).

15. Garde G.K., Sartha Vagabhat (Marathi), Mumbai Gajanan Book Depot, $7^{\text {th }}$ edition 1983, (Va. Sha. 3/61).

16. Brahmananda Tripathi, Charak Samhita vol. I (Hindi) (Varanasi Chaukhamba Surbharati Prakashan, reprint edition 2001, (Cha. Sha. $7 / 15)$.

17. Sushrut Samhita (Hindi) (Varanasi Chaukhamba Orientalia reprint $4^{\text {th }}$ edition 1980, (Su. Su.15/16).

18. Brahmananda Tripathi, Charak Samhita vol. I (Hindi) (Varanasi Chaukhamba Surbharati Prakashan, reprint edition 2001, (Cha. vi. 15/11).

19. Sushrut Samhita (Hindi) (Varanasi Chaukhamba Orientalia reprint $4^{\text {th }}$ edition 1980, (Su. Su.40/17 - 18).

20. Brahmananda Tripathi, Charak Samhita vol. I (Hindi) (Varanasi Chaukhamba Surbharati Prakashan, reprint edition 2001, (Cha. vi. 5/7). 
21. Brahmananda Tripathi, Charak Samhita vol. I (Hindi) (Varanasi Chaukhamba Surbharati Prakashan, reprint edition 2001, (Cha. vi. $5 / 21)$.

22. Brahmananda Tripathi, Charak Samhita vol. I (Hindi) (Varanasi Chaukhamba Surbharati Prakashan, reprint edition 2001, (Cha. Vi. 5/7).

23. Sushrut Samhita (Hindi) (Varanasi Chaukhamba Orientalia reprint $4^{\text {th }}$ edition 1980, (Su.Sha.4/16-17).

24. Sushrut Samhita (Hindi) (Varanasi Chaukhamba Orientalia reprint $4^{\text {th }}$ edition 1980, (Su.Su.21/10).

25. Charak Samhita With The Ayurveda Dipika Comentary Of Chakrapani Datta (Sanskrit) Varanasi Surbharati Prakashan, Reprinted edition 2002, (Cha. Chakrapani.Sha.7/10).

26. Garde G.K., Sartha Vagabha (Marathi), Mumbai Gajanan Book Depot, $7^{\text {th }}$ edition 1983, (Va. Su.11/5)

27. Sushrut Samhita (Hindi) (Varanasi Chaukhamba Orientalia reprint $4^{\text {th }}$ edition 1980, (Su.Su.15/6).
28. Garde G.K., Sartha Vagabhat (Marathi), Mumbai Gajanan Book Depot, $7^{\text {th }}$ edition 1983, (Va. Su. 11/25).

29. Garde G.K., Sartha Vagabhat (Marathi), Mumbai Gajanan Book Depot, $\quad 7^{\text {th }} \quad$ edition 1983 , (Va.Su.11/13).

30. Garde G.K., Sartha Vagabhat (Marathi), Mumbai Gajanan Book Depot, $7^{\text {th }}$ edition 1983, (Va. Su. 11/21).

31. Krishamurthy K.H. Bhela Samhita (Hindd Varanasi chaukhamba Vishvabharti, first edition 2000. (Bhel San. SU. 23/1-4).

32. Krishamurthy K.H. Bhela Samhita (Hindd Varanasi chaukhamba Vishvabharti, first edition 2000. (Bhel Sam SU.23/6-8)

33. Krishamurthy K.H. Bhela Samhita (Hindd Varanasi chaukhamba Vishvabharti, first edition 2000. ( Bhel Sam SU.23/5 P.G.102)

34. Krishamurthy K.H. Bhela Samhita (Hindd Varanasi chaukhamba Vishvabharti, first edition 2000. (Bhel Sam. SU.23/6 P.G.102) 